\title{
Emerging Gender Regimes and Policies for Gender Equality in a Wider Europe
}

\author{
GILLIAN PASCALL* and JANE LEWIS** \\ * School of Sociology and Social Policy, University Park, University of Nottingham NG9 2RD \\ email: gillian.pascall@nottingham.ac.uk \\ **DSPSW, Barnett House, 32 Wellington Square, Oxford OX1 2ER
}

\begin{abstract}
This article addresses some implications for gender equality and gender policy at European and national levels of transformations in family, economy and polity, which challenge gender regimes across Europe. Women's labour market participation in the west and the collapse of communism in the east have undermined the systems and assumptions of western male breadwinner and dual worker models of central and eastern Europe. Political reworking of the work/welfare relationship into active welfare has individualised responsibility. Individualisation is a key trend west - and in some respects east - and challenges the structures that supported care in state and family. The links that joined men to women, cash to care, incomes to carers have all been fractured. The article will argue that care work and unpaid care workers are both casualties of these developments. Social, political and economic changes have not been matched by the development of new gender models at the national level. And while EU gender policy has been admired as the most innovative aspect of its social policy, gender equality is far from achieved: women's incomes across Europe are well below men's; policies for supporting unpaid care work have developed modestly compared with labour market activation policies. Enlargement brings new challenges as it draws together gender regimes with contrasting histories and trajectories. The article will map social policies for gender equality across the key elements of gender regimes - paid work, care work, income, time and voice - and discuss the nature of a model of gender equality that would bring gender equality across these. It analyses ideas about a dual earner-dual carer model, in the Dutch combination scenario and 'universal caregiver' models, at household and civil society levels. These offer a starting point for a model in which paid and unpaid work are equally valued and equally shared between men and women, but we argue that a citizenship model, in which paid and unpaid work obligations are underpinned by social rights, is more likely to achieve gender equality.
\end{abstract}

\section{Introduction}

This article addresses some implications of transformations which challenge gender regimes across Europe. Gender regimes are seen as the key policy logics of welfare states in relation to gender. Challenges to the male breadwinner model have been widely noted. Equally, though less widely discussed, the dual worker model of Central and Eastern Europe (CEE) has been undermined since the collapse of communism by economic insecurity, with higher unemployment bringing an increase in women's dependence on men's incomes, and by changes 
in the state, especially reductions in legitimacy and in collective spending. The article will argue that these transformations in family, economy and polity have not been matched by new gender models. Widespread anxiety about reconciling work and family does not amount to widespread reconstruction of the systems underpinning welfare states' treatment of men and women, work and care. We shall map developing policies for gender equality across five components of gender regimes - paid work, care, income, time and voice - and argue the need for gender equality policies to be built across all component parts. We shall also consider these interventions in terms of different levels of intervention, at the individual, household, civil society and collective/social, and argue the continuing need for collectivity in care in the midst of markets, a model of gender based on citizenship, with obligations to care underpinned by rights to social support.

Individualisation of personal and public life is a key trend east and west, and challenges the structures that supported children and care in state and family. Market individualism has attacked the collective assumptions of western welfare states and the whole way of life of the planned economies of former communist countries. Social individualism - 'the pressure to put a life together under often contradictory and often incompatible conditions' - is a feature of the east as well as west (Beck and Beck-Gernsheim, 2002: 126). Women have fought to be treated as individuals. Individualisation may be especially potent for women, with liberation from traditional assumptions. But how can individualism be meshed with care? Gender regimes in the soviet era assumed equality of men and women as individuals in marriage and work, but were underpinned by collective assumptions about care. What kind of policies will create gender equality in the new wider Europe? Our aim is to transcend 'a woman-friendly policy approach' as a 'precondition for a productive post-industrial society' (Esping-Andersen et al., 2002: 94), and to map gender equality policies across a wider spectrum, constructing a holistic policy agenda.

\section{Challenges to Western European models}

The male breadwinner/female carer model, underpinning welfare policies of most Western European countries in the post-war era has been undermined by women's increasing labour market participation, political reworking of welfare/work relations, and family transformations, especially increasing divorce. Women's especially mothers' - labour market participation has been rising across most of Western Europe (Eurostat, 2000: 34). The decline of marriage and increase of births outside marriage undermine a male breadwinner system, which depended on low rates of divorce and of illegitimacy (Creighton, 1999: 525). The male breadwinner ideal has widely declined (Crompton, 1999; Lewis, 2001a). In the UK, the Beveridgean male breadwinner model underpinned policy from the $1940 \mathrm{~s}$ to the 1970s, and the Thatcher era still saw motherhood as women's first social obligation. New Labour has assumed that social obligation means paid work; 
but - despite expansion of care services - this great transition from careforce to workforce has modest social support and fragmented arrangements for childcare (Lewis, 2001b, 2002a; Moss, 2001; Land, 2002a, 2002b). No Western European country has put women on equal terms with men: even Scandinavian countries have labour market divisions which put women at a disadvantage in paid work and pensions, and discourage men's participation in care work.

\section{Changing CEE dual earner model}

What was the character of the gender regimes of CEE countries under socialism? Soviet policy challenged the male breadwinner model, identifying women's exclusion from paid employment as a key to their oppression and encouraging women to work outside the home (as well as in it) (Molyneux, 1990). Women's labour was crucial to economic development, and enabled through education, workplace social provision and state guaranteed parental leave and benefits, kindergartens and nurseries, and laws about marriage and the family that framed women as equal individuals (Fajth, 1996; UNICEF, 1998, 1999).

The gender regimes of the communist era appeared on the surface like Scandinavian ones, with women's high labour market participation and low gender pay gaps. At the point of transition, women's labour market participation rates were around 80 per cent in Czechoslovakia, Estonia, Latvia and Lithuania, and around 70 per cent in Poland, Hungary and Romania. The gender pay gap was 11 per cent in Hungary and 13 per cent in Poland (UNICEF, 1999: 24, 2001: 14). But the experience of gender equality as an imposition of authoritarian governments, rather than as an objective of social movements, made communist dual earner regimes feel very different from the inside:

Because of the impossibility of free public discourse gender relations never became a public issue. In public life, work, studies, culture, and politics, women had become (almost) equal, and they may have felt (almost) equal. But in the private sphere, in partner relations, within the family and the interpersonal arena, traditional ways of constructing men and women's roles remained, by and large, untouched. (Ferge, 1998: 221)

No civil society, and no pressures to bring men into household and care work in former soviet countries, brought distinctive regimes: these combined social and legal provisions supporting women's labour market participation, and legal equalities in marriage and divorce, with extreme domestic inequality, evidenced quantitatively by time use data (UNICEF, 1999; Gershuny, 2000).

Have the transformations since 1989 brought 'retraditionalisation', a reversion to the male breadwinner model? In Poland, in particular, this case can be argued, as a consequence of the strength of the Catholic Church and Solidarity, and the reaction against soviet domination. Abortion has been much debated, and is now restricted except in exceptional cases. One of Solidarity's first actions was to cut maternity leave and leave benefits. Reduced from six 
months' full pay, six months' reduced pay, and six years' unpaid leave under communism, mothers in the public sector can take six months with reduced pay, while in the private sector they may not be eligible at all (Bystydzienski, 2003). Education has not protected women's jobs, and there is an increase in the proportion describing themselves as keeping house (Glass and Kawachi, 2001). Current figures show women's employment rates mainly below the EU average: women's 'relatively favourable position in the labour market, which had made the region comparable to Sweden, the leader in the West in this regard, is now a phenomenon of the past in most transition countries' (UNICEF, 2001: 14). Men have lost jobs too, and a return to male breadwinner households cannot be read off from these data, but men's employment rates across CEE accession countries are now above women's (Eurostat, 2001a: 17).

The transition from communism threatens many aspects of the dual earner systems of CEE countries, with changes in GDPs, the ability to raise taxation, and ideological support for state services. The gender regimes of the soviet era were built on very high levels of public expenditure of around 55 per cent of GDP in the countries of Central and South-Eastern Europe. The comparable figures now are 45 per cent in CE and 40 per cent in SEE (UNICEF, 2001: 13-16), leading to reduced spending on child care, education, health, pensions and child benefits, and pluralisation of welfare instruments (Ferge and Tausz, 2002). But several CEE accession countries have retained their strong tradition of state involvement in childcare. Social spending cuts have tended to close state nurseries, but the tradition of pre-primary school enrolment has been sustained, albeit unevenly: Hungary has 87.3 per cent of 3-6 year-olds enrolled and the Czech Republic 85.4 per cent, while Poland has the lowest number enrolled at 49.9 per cent (UNICEF, 2001: 147; Walters, 2003): gender regimes in this respect are close to Scandinavia in style, albeit at much lower living standards.

Transition to market-based democracy brings transition to a new gender order, and poses critical practical dilemmas over parenthood and care: 'With the retreat of the state from daily life, these societies must now fill in the blanks in the interdependent arrangement of work and family' (UNICEF, 1999: 57). But the new arrangements emerging may not just be a return to traditional models. Most discussion has focused on paid work and on politics. But, from inside households, there begins to emerge evidence for a more equal distribution of care work, in radical transformation from the strongly gender stereotypical roles of the communist era. The European Foundation now finds a more egalitarian distribution of care in the 12 Accession and Candidate Countries than appears on average elsewhere in Europe, with 31 per cent of men involved in raising and caring for children, compared with 24 per cent in the EU (Paoli and ParentThirion, 2003: 78). These changes appear particularly associated with younger men (Bystydzienski, 2003). The combination of continued state provision for young children, with changing gender practices within younger households, 
suggests that CEE countries are not going back to the past, but are developing something new, which could bring more gender equality, with deeper social roots than under communism.

\section{Gender regimes in a wider EU}

Gender regimes at the national level are increasingly influenced by EU-level legislation, where the politics of reconciling work and family have gained increasing purchase (Williams, 2001; Duncan, 2002). Concern with the domestic gender relations that underpin work inequalities appears in Directives on Parttime work, Working Time and Parental Leave and on research on reconciling work and family (European Commission, 1999; Neilson, 1998; Rossilli, 1999, 2000). The Social Policy Agenda asks the social partners to 'strengthen their dialogue with particular attention to... reconciliation between family and working life' and aims to prepare the enlargement of the Union under conditions of 'balanced economic and social development' (European Commission, 2000: 21-2).

Balanced gender development is a major challenge. Former communist countries risk being absorbed within western paradigms, which will not support care work or household incomes, while incomes remain low by western standards and the private solutions adopted by the better-off people in better-off countries will be generally unavailable. The example of the former GDR offers a foretaste of the likely consequences of absorbing former soviet societies into western models of social policy: having children at all has become laden with dilemmas (Beck and Beck-Gernsheim, 2002). The level of integration involved in merging the former East and West Germany is not to be expected from EU enlargement. But some convergence will occur and will have implications for CEE gender regimes.

The social implications of this 'historic enlargement' (D-G, 2000: 2) have received little attention (Hantrais, 2002a; Pascall and Manning, 2002). It joins countries with contrasting gender regimes. While Malta retains a traditional male breadwinner regime, CEE countries - ten from the former soviet region, with the Czech Republic, Estonia, Hungary, Latvia, Lithuania, Poland, Slovakia and Slovenia members from 2004 - have had legislation supporting women as paid employees and mothers, pre-dating Scandinavia.

\section{Gender models in the new Europe}

If both the key models - East and West - for connecting paid work and family, incomes and unpaid work, are crumbling, are there alternatives?

More debates concern the aftermath of the western male breadwinner model than the future of the dual earner model in CEE countries (Crompton, 1999; Fraser, 1997; Lewis 2001a, 2001b; Gornick and Meyers, 2003). These may be analysed into models based on different levels of intervention in policies for gender equality. The most individual, represented currently by the US (and to some extent Britain) offers women as individuals the right to gender equality 
at work, but limited public responsibility for the costs of children brings 'problems of income and time poverty, gender inequality, questionable child care arrangements, and poor outcomes for children'. Its 'exceptionally private conception of family life leaves American families to craft individual solutions to what is essentially a social dilemma: if everyone is at the workplace, who will care for the children?' (Gornick and Meyers, 2003: 8). The authors make a powerful case for the US to move from its individualist assumptions.

A model of intervention for gender equality at the household level is the Netherlands' 'Combination Scenario', set out in a White Paper in 1997, and intended to bring equality of unpaid work by 2010. This offers a new direction, with the aim that men and women should equally be able to combine paid and unpaid work, thus bringing men into unpaid work, as well as bringing women into paid. This involves a range of policies, including changes in taxation policy, and policies on working time. Reality remains a long way from the ideal that paid and unpaid work should be equally valued and shared, with mothers much more likely than fathers to do part-time work, though policies on working hours (below) make a significant contribution (Knijn, 2001; Lewis; 2002a; Mutari and Figart, 2001; Plantenga, 2002). We shall argue that redistribution of care work at the household level is a crucial component of any future model, but some households have more resources for care than others: a model of gender equality needs to look at the distribution of responsibility between households as well as within them.

At the level of civil society, Fraser argues for a 'universal caregiver' approach in which all employees would be assumed to have care responsibilities. Some care would take place in households, and some in state-funded settings, but there would also be major developments in civil society, where people without care responsibilities would 'join parents and others in democratic, self-managed care work activities' (Fraser, 1997: 61-2). These ideas bring new ways of resolving dilemmas between work and care, bringing men into care and generating new organisations in civil society. But are there limits to what can be achieved at this level, particularly in CEE countries, with newly developing civil society and extreme pressures on money and time?

Finally, a dual earner-dual carer model of gender, based on citizenship, would bring gender equality in employment, emphasising equal access to jobs in quality and quantity: a two x three-quarter earner model instead of one and a half. It would bring men into care work in households, but would also recognise households' need for social provision. Analyses of gender models have been developed mainly in Europe (Crompton, 1999; Lewis, 2001b) but the most developed account is Gornick and Meyers' (2003) synthesis of European policies for an US audience. They argue for children to be seen as a social good, needing to be socially supported to avoid non-parents' free-riding on parents, through policies for parental leave, regulating working hours and quality social care for children. These ideas draw from European states, and could be further developed 
in the wider Europe, where a major tranche of states have a tradition and continuing practice of social investment in children quality childcare. We will argue that the evidence of gender equality policies in practice highlights the need for policies involving collective provision across different dimensions of gender regimes.

Current practice offers a variety of approaches, with only Scandinavian versions approaching gender equality across paid work, care work, income, time and voice. Scandinavian women's full-time work - or long part-time hours are combined with social care outside the family: there are consequences in occupational segregation, with women in public sector occupations, but low gender pay gaps and greater equality of work within households. In the US, women's full-time work is supported mainly by privatised care, with many consequences for time and the quality of care, as well as deep social divisions in work (Gornick and Meyer, 2003). In Germany, the Netherlands and the UK, the emphasis - despite some change - is on women's part-time work covering care, bringing major gender differences across all dimensions. In CEE countries, care needs have been reduced by falling birthrates: the highest total fertility rate among CEE countries is Poland's at 1.4, while the lowest is the Czech Republic at 1.1 (UNICEF, 2001: 128). CEE countries retain social care for three to six year olds, but public policy is male dominated and assumes women as carers, making women's employment insecure, and using parental rights risky. In the US, unequal incomes bring unequal care, in the UK unequal time brings unequal incomes, and in CEE countries unequal voice brings unequal security of work.

Policies for gender equality drawn from a variety of countries in Europe, and from the policy literature, are mapped in Figure 1, across different levels of policy intervention identified above, at individual, household, civil society and collective levels. Many gender equality policies are aimed primarily at individuals, to change individual women's ability to compete with men at work. The literature and the policy environment show a growing awareness of the need to intervene at the household level, with policies to enable households to manage care, and particularly to encourage men to engage in care. Civil society is a crucial source of political change in CEE countries, and also an important provider of care in some western countries. Policies at the collective level allow resources to be shared between households as well as within them.

Gender equality policies are also mapped in Figure 1, across the essential elements of gender systems: their allocations of paid work, care work, income and time, and voice, between men and women and between households and the state. We draw on Creighton's argument about the decline of the breadwinner model, whose analysis of the systemic nature of the model argues the widespread implications of its decline, but we follow this through into a systematic analysis of policies (Creighton, 1999). We also draw on Daly's mapping of care policies, but focusing on care rather than on gender (Daly, 2001, 2002). We will argue that gender equality policies have been limited in effect, because they have addressed 


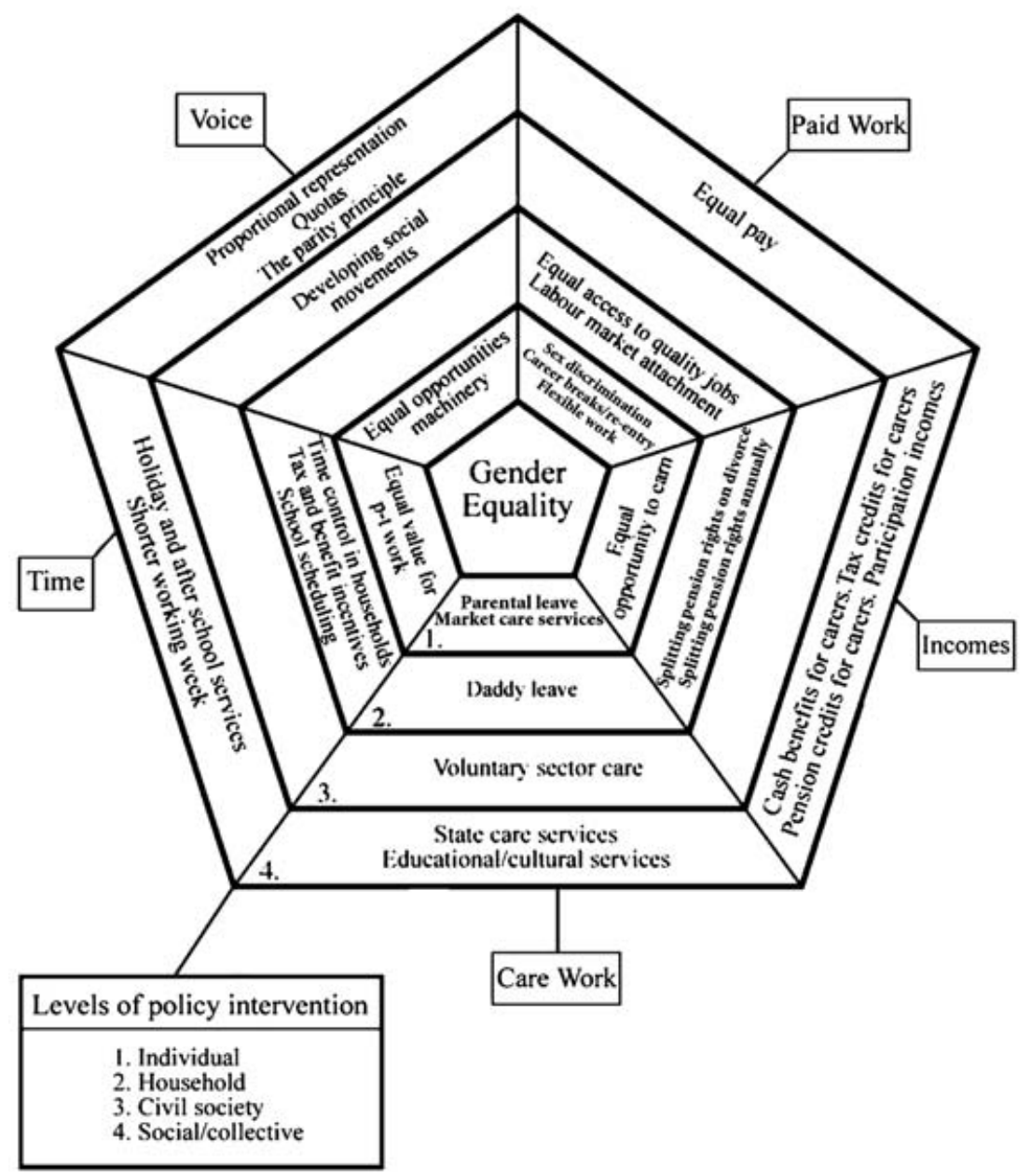

Figure 1. Policies for gender equality.

part of the system rather than the whole: in particular, individual women's possibilities for equal earning. But gender regimes are interconnected systems, through which paid work is connected to unpaid work, state services and benefits are delivered to individuals or households, costs are allocated, and time is shared between men and women in households, as well as between households and employment. If gender equality policies are to be more effective in delivering equal treatment, in paid work and welfare, they need to address the interconnecting elements of gender regimes as systems, with a logic of gender equality in care work, income, time and voice, as well as in paid employment. This means developing an environment favouring more equal shares between men and women in paid work, care work, income, time, and voice, between individuals within households and in paid work and politics. 
First some caveats: different contexts may bring different consequences. Part-time work may be a strategy for bringing women into the labour market and shaking traditional assumptions about women's roles (as recently in the Netherlands) or for marginalising them (as in the UK) (Fagan, 2001). Quotas for representing women in parliaments have been used for women in Scandinavia, but have been damaging in former communist countries as part of the communist state. Some policies will be robust in different circumstances, but any assessment needs to be sensitive to circumstance, and to the detail of implementation. Second, some policies on the map could be classified in different ways: for example, leave policies could be seen primarily as creating time for childcare, or as enabling attachment to work. Finally, the levels of intervention have been arranged from individual, through household, civil society and collective/state. This enables us to distinguish between policies aimed at enabling women to keep doing paid and unpaid work, such as maternal leave, and those aimed at encouraging sharing, such as paid Daddy leave: but payment for Daddy leave goes to individual men, who may or may not share it with partners/wives. We have used the fourfold classification in order to distinguish between policies that are aimed at individual women and those aimed at households, and in order to represent the importance of civil society in developing CEE politics, as well as some care provision. But we argue that the most important division is between policies which rely on households to produce gender equality, and those that acknowledge the importance of the wider society, particularly at the collective level.

\section{Paid work}

Legislation to outlaw sex discrimination, to give women, as individuals, equal access to jobs, backed by the courts, has played a role in bringing women into the labour market on more equal terms with men in some countries of Western Europe. It has been important to women's independence within relationships and survival outside. In CEE countries under communism career breaks and re-entry to work enabled mothers to move freely between work and family obligations, while parental leave under market conditions brings the risk of discrimination against women. Flexible work individually controlled could mean increasing both parents' control over schedules, but flexibility has tended to belong to employers (Bettio et al., 2000).

Where parents are accommodating care, gender differences in labour market attachment, continuity and flexibility are much more evident. Across the EU 15, 71 per cent of working age men are in employment compared with 51 per cent of women. That 33 per cent of women in employment are working part-time compared with 6 per cent of men suggests that women still accommodate unpaid family work (Eurostat, 2000: 34; Bettio et al., 2000; Fagan et al., 2001; Hakim, 2000; Rubery et al., 1998a, 1998b, 1999). Men's lifetime earnings are higher than 
their partners': in the UK among couples with children - on average - women's earnings are half men's (Rake, 2000). Equality at work could mean equal access to quality jobs, with equality of labour market attachment, to enable households to share both paid and unpaid work. Rhetoric across the EU supports reconciling work and family, but few policies aim to share work more equally between men and women, unless to bring women into the labour market on the same terms as men. (Policies around part-time work and parental leave are discussed below.) Such policies could offer men and women a prospect of time and flexibility for reconciling work and family, and developing civil society. Men would also have time to care, though it might take more than time to persuade them to do so.

Equal pay legislation has brought a measure of gender equality in full-time employment, where women's work matches men's, especially among younger, more highly educated women: across the EU 15, women full-time workers earn 74 per cent of the amount of men full-time workers. Lower pay gaps have been achieved in Scandinavian and CEE countries, around 80 per cent, where women's employment has been underpinned with state services, nursery provision and parental leave (Eurostat, 2000, 2001a). Labour market policies have brought women into paid employment across Europe, but the key to more equal treatment has been a collective approach to care.

\section{Incomes}

Women are clearly seeking a more equal opportunity to earn: equal pay, a fairer share of quality work, decent minimum wage levels, and sufficiency of work for self-support are crucial to women in individualising societies. The collapse of work in some CEE countries, especially for women, threatens women's ability to earn incomes or pensions, while social investment declines. A return to higher levels of paid employment must be part of any solution to the position of women in the post-communist countries.

Policies to bring equal rights to pension and benefit incomes in households could contribute to gender equality. Women tend now to be seen both as primary carers and as individuals responsible for earning for themselves, their children and their own pensions. In the context of the gendered division of care work, equal pensions resulting from equal lifetime earnings are a distant prospect. Reforms extending private provision at the expense of the public have tied pensions more closely to lifetime earnings and 'threaten to magnify gender inequality in later life income' (Ginn et al., 2001: 230). Social insurance systems need radical change if they are to recognise care work as civic duty equally with paid employment and recompense care with contributory benefits. Splitting pension rights on divorce is already the practice in Germany and the UK. A more radical option would split pension rights annually, as in Switzerland: 'half of the husband's pot would be tipped each year into the wife's pot, and half of the wife's pot would be tipped 
each year into the husband's pot' (Barr, 2001: 150). This would acknowledge the differential impact of care work on men's and women's lives and reduce its consequences for income in old age.

For those with care responsibilities and less labour clout than under communism, access to income is a crucial issue now, east and west. Policies to bring incomes to carers, such as cash benefits, tax credits, or pension credits for carers, have hazards: low, conditional incomes, entrenching the gender division of care work (Daly, 2002: 264). Compensating care through basic income (Jordan, 1989, 2000) or participation incomes (Atkinson, 1998) would bring a clearer political recognition and valuation of care as work. These would also provide a more flexible environment for people's decisions about combining paid and unpaid responsibilities. The problems lie with funding sufficiently to provide a worthwhile income. Participation incomes could form part of a system aiming to give individuals time to combine paid and unpaid work. Individuals' opportunities to earn meet only part of the need for income, especially for those with care responsibilities.

\section{Care work}

Women's sole responsibility - sometimes for 24 hours a day care of vulnerable young and/or older people - has limited their access to incomes, but also to voice, inside relationships and out, in civil society and the public sector. The extent of women joining the labour market - whether in CEE countries or western Europehas not been matched by men joining responsibility for work in the household. The gender division of unpaid work has been seen as a 'stalled revolution' in the USA (Hochschild, 1989) and a 'care crunch' in Australia (Hancock, 2002). Broad international trends show some convergence between men's and women's unpaid work (Gershuny, 2000). But everywhere, women are likely to be primary carers and manage flexible working lives. Even in social democratic countries, policies for getting women to do more paid work have been more extensive than policies for getting men to do unpaid work. In soviet regimes, women were conceived as workers and brought into the labour force. But this was done by state support for women's care work and not by transforming the domestic division of labour. The European Union scarcely recognises unpaid care work, with gender policies rooted in a conception of women as an actual or potential workforce in the market.

But - in the teeth of this broad picture - fathers have come into social policy and family law dialogues. In post-male breadwinner states it can no longer be assumed that fatherhood means providing. Partnerships are more negotiated than they used to be (Lewis, 2001b). Policy debates are still dominated by the idea that reconciling work and family means improving conditions for women to do both. But debates around caring fatherhood and parental leave have brought 
some change in some countries (Hobson, 2002; Knijn and Selten, 2002; Lewis, $2002 b$ ). Policies to promote men's share of care work are only beginning, but this is a crucial part of the jigsaw if women's care work hours are to be reduced especially in CEE countries - care work valued, and paid work shared more equally between men and women.

Various kinds of parental leave may be seen as enabling women's labour market participation or as promoting men's care work. Under communism, it was clearly the first: parental leave in CEE countries can in principle be taken by either parent, but men's participation remains negligible: often less than 1 per cent (UNICEF, 1999). Now greater insecurity of work makes it more difficult for either parent to use entitlements (Fodor et al., 2002). Sweden since 1975 has offered leave to either parent, with generous and flexible benefits, and, again, has mainly encouraged women's labour market participation. Most policies enable women's labour market participation and improve - to some extent - their access to independent incomes and their public voice. But taken largely by women, leave may damage women's labour market position, promote their labour market exit, entrench their caring roles, and exempt fathers. Unpaid leave is not affordable for poorer parents. Men are unlikely to take leave unless it is paid (Moss and Deven, 1999).

Parental leave that is paid, shared between men and women and combined in a wider environment of policies for gender equality in work and family, may, as in Norway and Sweden, begin to challenge traditional parenting roles (Leira, 1999). Daddy leave, a period of paid leave designated for fathers, is the first significant policy to change men into carers, rather than women into workers. Among Swedish children born in 1995, 77 per cent had fathers who used the whole month then available. Swedish fathers still take much less leave than Swedish mothers and maternal care remains a norm (Bjornberg, 2002). But research suggests that taking parental leave affects men's thinking about work and family and their subsequent participation in childcare (Haas and Hwang, 1999). Now Sweden has two months Daddy leave, and Italy has introduced incentives to men to take a larger share of the (partially paid) parental leave: fathers who take three months parental leave bring an extra month's entitlement (Krause, 2003).

In countries lacking public childcare services, such as the US and the UK, the development of market care services has enabled better-off parents to combine paid work and family. Relying on markets means that gender equality is likely to be a privilege (nearly) attained by better-off women - as currently in the UK where reliance on the private sector has led to contrasting patterns: more highly educated women pay for childcare and develop continuous careers whereas the less highly educated return after childcare to low-paid part-time jobs and suffer a huge loss of income. Integrated childcare and education services, on a universal basis, and 'long-term investment by Government' are needed to change this in the UK (Land, 2002a: 12; Rake, 2000). The voluntary sector has some importance in 
care services, but generally lacks the capacity for childcare to underpin women's labour market participation. All these underline the importance of the state in regulating, funding and providing early childcare services.

State care services may be seen as social commitment to children and disabled or older people. But under conditions of gender inequality in paid and unpaid work - which are likely to persist - they may also be seen as compensation for women's unpaid care work, through redistribution from earners. They set limits to care responsibility for individuals, moderating unpaid work, and giving time for paid work, for carers to earn incomes and pensions. They have been crucial to women's high labour market access in Sweden and in Central Europe. Some aspects of CEE social policy regimes have survived the upheavals: 'A long history of low income inequality, combined with a tradition of investment in the social sectors in general and in children and the family in particular, have left a lasting mark' (Micklewright and Stewart, 2000). Unless care is underpinned with public services, gender equality will belong to the better off. Secure care involves state provision as well as state and EU regulation.

EU policy about reconciling work and family includes a Council Recommendation on Childcare covering principles for care services, leave arrangements, workplace changes and men's participation in care (1992) and the Parental Leave Directive (1996). There is therefore 'a common agenda for European early childhood policy: a legal right to maternity and parental leave; public support for working parents; and public support for a period of early education available to all children before they start school' (Moss, 2001: 10). But implementation is varied (Cohen, 1999), there is more soft law through the Open Method of Co-ordination than firm directive, and the EU - along with national governments - has done more to bring women into paid work than men into care (Neilson, 1998; Mazey, 1998; Walby, 1999; Ostner and Lewis, 1995; Ostner, 2000; Rossilli, 1999, 2000; Hantrais, 2002b). Former communist countries have lost subsidised educational and cultural services for children out of school hours. High-quality services for children of all ages - and equal access to paid employment for mothers - are unlikely to be guaranteed without state involvement in regulation and provision (Gornick and Meyer, 2003).

\section{Time}

Whatever the convergence between countries, between men and women, and between social classes (Gershuny, 2000) the distribution and meaning of time remain profoundly gendered. In CEE countries, women have paid a high price for their jobs in hours of paid and unpaid work and little leisure, in the context of a lack of part-time work, and long working hours (Paoli and Parent-Thirion, 2003). The male breadwinner model leaves residues in most western countries of differences in working hours, part-time work, rewards from work, and the balance of work and care responsibilities. Men prioritise paid work, leaving 
women to manage flexible part-time work and family responsibility. This pattern contributes to gender inequality and to undervaluing care as a marginal activity, hidden in private life. Social policies - unregulated working time, inflexible male-style working life patterns, maternity leave, benefits systems based on a male worker model of employment - have often supported these differences. But social policies also offer routes to transform the gendering of time. To achieve this, they would need to address the quantity of working time, its distribution between men and women, and between households, as well as autonomy for individuals to control working time in the interests of care and leisure. Time policies for care of elderly or disabled people are particularly under-developed (Daly, 2002: 258-9). These are key issues if welfare is for well-being, rather than just work and wages (Lewis, 2002a).

Flexibility and fairness are targeted in policies of equal value for parttime work, supported by the European Directive on Part-time Working, and by legislation against discrimination between employees based on working hours in the Netherlands. Dutch women's part-time work is on a fairer basis than in the UK, where women's part-time work is particularly poorly valued (Fagan, 2001; Grimshaw and Rubery, 2001; Plantenga, 2002). These policies should enable households to negotiate, adapt and share working hours more equally. But policies have been more focused on changing women's use of time than on changing men's. In the Netherlands, women's move into part-time work has been rapid, but the official Dutch ideal of a combination model for both sexes is still far from reality. Men's part-time work has increased, but as young and older workers, rather than as parents (Plantenga et al., 1999; Plantenga 2002). These policies have served to bring it into line with the Western European norm of a one and a half worker pattern, with women as the half, rather than transforming the gender division of time.

Time control in households is crucial for carers of young children, disabled or elderly people, who are unlikely to make themselves available for work that imposes uncertainty or inflexibility: households need control over flexibility and autonomy to manage time, while being responsive to and responsible for vulnerable members. The transformation of work could make space for flexible working enabling households to mesh family work with paid employment. But flexible working has tended to work for firms rather than for individuals, and to undermine households' capacity for safe and consistent care: 'A renegotiation of the time-based employment contract can be identified as an essential prerequisite for a new gender contract ... a lifecycle approach to flexible working time... would allow eventual change in the distribution of parenting work' (Bettio et al., 2000: 148). School scheduling to match work times, holiday and after-school services, family leave, flexible parental leave, working time based on flexi-years - these could all be extended to maximise people's control over their own working lives (Gershuny, 2000). Time convergence policies in tax and 
benefit systems would undermine a key reason for the failure of gender equality policies. National taxation and social security policies and overtime regulations could offer incentives to move away from unequal one-and-a-half patterns in Western Europe. This might involve incentives to employers and employees, especially men, through insurance contributions favouring intermediate hours; or individualising taxation systems to discourage differentiated gender roles (Bettio et al., 2000: 154).

A shorter working week would give men time for care, women access to paid work and both space for children. Europe's Working Time Directive offers a maximum of 48 hours and makes a beginning. There is evidence of some convergence between men and women (Gershuny, 2000) and more evidence that men and women in EU states would welcome more convergence, reducing men's tendency to long working hours, and women's tendency to short part-time, preferring a working week around 37 hours, near the current average working week for all workers of 38 hours (Fagan et al., 2001; Bielenski et al., 2002). In Western Europe, shorter working hours would close the gap between parttime and full-time employment, reduce the segregation of the labour market and challenge long-hours culture (Creighton, 1999). The working time regimes in CEE countries differ from those in Western Europe: CEE workers have longer hours, at an average of 44, with few part-timers (Paoli and Parent-Thirion, 2003: 45). In CEE countries, shorter working hours for men could bring women out of unemployment, sharing employment within and between households. France has the strongest policy for the shorter working week, with a maximum of 35 hours, introduced to share work between households, but enjoyed in France for its familyfriendly consequences (Boulin, 2000; Fagnani, 2002a, 2002b). Denmark has a collectively agreed 37 -hour full-time week, and Belgium a maximum of 39 hours (EIRO, 2002). Reducing the maximum working week could be a strong policy for gender equality, sharing work between men and women and reducing poverty by spreading work, working within households as well as between them. Policies to hasten time convergence between men and women, within and between households - in contrast to policies enabling women to cover care would offer gender equality in time for work, care, civil society and public politics.

\section{Voice}

Equal opportunities machinery, offering individuals rights to claim equal pay and opportunities through recourse to the courts, has brought important rights to individuals. But still, inequalities in paid work, care, income and time bring unequal voice in households, civil society, local politics, state and European governments. In households, the continuing gender division of labour suggests that women's voice is weaker, and their lower incomes may give them less say in major decisions than men. Household decision-making processes appear to be connected to wider structures of labour markets and welfare states, as well as to 
gender ideologies and inequalities of power within the household (Morris, 1990). The evidence suggests the need for looking to, but also beyond, women's paid employment, for sources of change in the voice of women in households and their ability to affect household spending and the domestic division of labour. Welfare states can encourage equality within households by policies that support equality outside it.

Developing social movements are also significant for representing women's interests and for gender equality. The emergence of collective action by carers has brought issues of care from individuals in households into public politics in the west, bringing collective identity, recognition and policy development (Barnes, 2001). Under communism, the lack of civil society and women's action within it brought a wide gap between public equality and domestic tradition, and its lack now exposes the gains of the communist era in women's position in public life. Equal opportunities machinery is limited in CEE countries (UNICEF, 1999: 106). It will be difficult for women to know their rights without extensive development of local legal advice and national organisations.

Women's representation in government and politics is generally low: for example, in Western Europe the representation of women in parliaments is currently around 15 per cent. The Nordic countries manage much more at 39 per cent. It has taken the UK 84 years, from when some women were first allowed to vote in 1918 to reach a parliamentary representation at Westminster of 18.2 per cent, a level that undermines representation itself (Phillips, 1991, 1998). Under communism in the 1980s, quotas brought women's representation in parliaments to around 30 per cent. But gender equality was owned by the communist state rather than by women themselves, and women's position in parliaments gave them little political power. The suppression of civil society inhibited the development of a women's movement. Gender equality in CEE countries has been contaminated by communism: transition from communism brought a drop in women's representation in parliaments to around 5 per cent. Development of civil society during the transition period may have brought more real involvement in local government, NGOs and grassroots economic and political activities and a gender politics of the household. But the new political structures in CEE countries are more male dominated than the old (UNICEF, 1999: 93-108; Pascall and Manning, 2000).

If these political conditions owe a lot to gender inequalities in paid work, care, income and time they, in turn, undermine representation of these issues. Women need a voice for caring issues in formal, informal, national and international contexts (Lister, 1997: 202; Siim, 2000). International bodies agree the need to represent women fully in democratic processes, through the UN's Convention on the Elimination of All Forms of Discrimination against Women in 1979 (UNICEF, 1999: vii) and through a Council of European Union Recommendation calling on member states to increase representation of women in decision-making positions 
(Squires and Wickham-Jones, 2001: 1-5). But soft law has not put serious pressure on national governments. Accumulated evidence suggests that discriminatory political processes are the key to the weak representation of women - rather, for example, than women's choices or poorer qualification for election (Elgood et al., 2002; Phillips, 1991). More representative government in Scandinavian countries has been achieved through proportional representation, quotas, the strength of women's organisations in the parties and a shifting public-private divide. These have formed a cycle that improves women's situations in politics and households (Phillips, 1991). These changes are more deep-rooted in Nordic countries than elsewhere. But in May 2000, France regulated the proportion of women candidates in local, regional and European elections, though not in parliamentary ones. This 'parity law' produced a dramatic increase in women's representation from 22 per cent to 47.5 per cent in the cities in March 2001 (Squires and Wickham-Jones, 2001). The parity principle suggests that the representativeness of political institutions could be improved radically and rapidly, if the Council of Europe were to turn recommendation into directive to member states to increase women's representation in Europe itself, and in national and local assemblies, following France's lead and taking it further, disseminating good practice. Representative government, fully including women, would bring better prospect of gender equality in work, incomes, time and care, with consequences within households and between them.

\section{Conclusion}

There is no single magic policy for gender equality. Rather, the gender assumptions underpinning economic and social policies need to be examined very widely and the interconnections of paid and unpaid work, income, time and voice acknowledged. Policies directed at paid work have been very successful in some countries and under some conditions: they have increased women's access to incomes for themselves and their children, and to pensions; they have given women more voice in relationships and in public politics. They are still needed to reduce men's incentives to work longer hours than their wives/partners. But even in the most favourable countries, women earn less than men: gender equality in the labour market alone is unattainable, because of systemic connections to inequalities in families, politics and civil society.

Mapping gender equality policies has also raised the question of interventions at different levels, from individual, through household, civil society and state. Policies enabling individual women to achieve equality with individual men policies against sex discrimination, for parental leave, for equal opportunities have brought women into the labour market and supported their ability to care for children. For women with higher education they have brought well-paid work and the capacity to pay for care. But they have created diversity in labour markets and in households, with gender equality accessible only to advantaged women. They 
have also brought gender equality to women on men's terms, enabling women to balance work and family, but offering no challenge to men to do the same.

The Dutch Combination Scenario offers a new vision of households in which men look after children too, discouraging men's free-riding on care work. Social value for unpaid work, community work and child-rearing lie behind the Dutch 'post-productivist' regime: it brings choice to households over reducing and sharing working time, time autonomy to individuals, adequate incomes, and strong economic growth (Goodin, 2001). Its ideals of gender equality go beyond other models, in their relation to time and value for unpaid work as well as paid.

The 'Combination Scenario' and Fraser's 'universal caregiver' models expect too much of households and civil society, rather than governments, moving care towards private and informal paid care, not supported by public provision (Knijn, 2001). In CEE countries civil society is developing, but not developed, and long working hours leave little time for creating new community services. A policy environment aiming to give people more equal time to care for themselves and others might lead to lower spending levels than in the social democratic and former communist regimes, and make the gender equality aspects of these regimes more transportable-addressing the 'Achilles heel' of the Nordic approach (Esping-Andersen et al., 2001: 25, 2002). But we have no evidence yet of regimes producing gender equality without significant public expenditure and provision.

There are social class and age differences in the ability of households to support care work, to which a response at the level of collective services and transfers is needed. A gender model that aims for more equal incomes between men and women must acknowledge the needs of those who have prioritised care, accommodating the choices of women made within moral and policy contexts that made the 'choice' of self-support surrender to the 'choice' of care (Hakim, 2000). Household-level policies, designed to share pensions or time more equally, can make a contribution to policy, but a wider context of collective services and transfers will produce wider gender equality.

The significance of collective provision is evidenced by those regimes that have actually produced a degree of gender equality, especially Scandinavian and CEE countries. Their more egalitarian legislation and smaller gender differences in pay, incomes and household time have been achieved in part through public expenditure and commitment to collective care. If citizens have responsibilities for care and responsibilities for work, they also need the rights to support care. These rights have been achieved through redistributive policies countering gender discrimination in employment and supporting care work when carers are not supported by or joined to breadwinners.

An inclusive citizenship version of the dual earner-dual carer model would create a policy environment encouraging gender equality in paid work, care work, income, time and voice, while offering social support for care and for work. It would aim to share quality work between men and women, replacing the one 
and a half earner model developing in much of western Europe with a two $\mathrm{x}$ three-quarter model, and to re-establish full employment for women in CEE countries, while reducing long working hours. Social policies would assume that men and women equally need to earn for their own security and should have equal obligation to care for children and others. Policies for equal pay would be joined by policies for sharing quality work, to increase equalities of incomes and security. Regulating full-time work - through reducing full-time hours and sharing it between men and women would give time for both to share unpaid work, while education, benefit, taxation and pay policies support equal care. Greater equality of voice for men and women in households and in public politics could be fostered by changes in political processes. A model equalising paid work, care work, income, time and voice would build the necessary links between care and income which have been severed by recent trends. It would allow people as individuals to support themselves while finding time for commitment to family. But neither households, nor civil society, can create gender equality or reconcile individualism with the need for care without collective commitments to children and others. The best prospect for gender equality in the new Europe is a model in which people's obligations to paid work and care as citizens would be underpinned with public investment in citizenship rights.

\section{Acknowledgement}

Thanks are due to Stuart Pearson for his help with Figure 1.

\section{References}

Atkinson, A.B. (1998), Public Economics in Action: The Basic Income/Flat Tax Proposal, Oxford: Clarendon Press.

Barnes, M. (2001), 'From private carer to public actor: the carers' movement in England', in M. Daly (ed.), Care Work: The Quest for Security, Geneva: ILO, pp. 195-210.

Barr, N. (2001), The Welfare State as Piggy Bank, Oxford: Oxford University Press.

Beck, U. and Beck-Gernsheim, E. (2002), Individualization: Institutionalized Individualism and Its Social and Political Consequences, London: Sage.

Bettio, F., Rubery, J. and Smith, M. (2000), 'Gender, flexibility, and new employment relations in the European Union', in M. Rossilli (ed.), Gender Policies in the European Union, New York: Peter Lang, pp. 123-58.

Bielenski, H., Bosch, G. and Wagner, A. (2002), Working Time Preferences in Sixteen European Countries, Dublin: European Foundation for the Improvement of Living and Working Conditions.

Bjornberg, U. (2002), 'Ideology and choice between work and care: Swedish family policy for working parents', Critical Social Policy, 22: 1, 33-52.

Boulin, J.-Y. (2000), Actual and Preferred Working Hours in the EU: National Background for France, Dublin: European Foundation for Living and Working Conditions.

Bystydzienski, J. (2003), 'Poland', in G. Walter (ed.), Women's Issues Worldwide: Europe, Westport, CT and London: Greenwood Press.

Cohen, B. (1999), 'Parental leave in Europe: policy implications', in P. Moss and F. Deven (eds.), Parental Leave: Progress or Pitfall?, Brussels: NIDI CBGS Publications, pp. 293-302.

Creighton, C. (1999), 'The rise and decline of the "male breadwinner family" in Britain', Cambridge Journal of Economics, 23: 519-41. 
Crompton, R. (1999), Restructuring Gender Relationships and Employment: The Decline of the Male Breadwinner, Oxford: Oxford University Press.

Directorate-General for Information and Public Relations (D-G) (2000), A Strong Union needed for a Successful Enlargement, Luxembourg: Office for Official Publications of the European Communities.

Daly, M. (2001), Care Work: The Quest for Security, Geneva: International Labour Office.

Daly, M. (2002), 'Care as a good for social policy', Journal of Social Policy, 31: 2, 251-70.

Duncan, S. (2002), 'Policy discourses on "reconciling work and life" in the EU', Social Policy and Society, 1: 4, 305-14.

EIRO (2002), 'Working Time Developments - Annual Update 2001', EIRO Online, http: www.eiro.found.ie.

Elgood, J., Vinter, L. and Williams, R. (2002), Man Enough for the Job? A Study of Parliamentary Candidates, Manchester: Equal Opportunities Commission.

Esping-Andersen, G., Gallie, D., Hemerijck, A. and Myles, J. (2001), 'A new welfare architecture for Europe', Report Submitted to the Belgian Presidency of the European Union, CEC, Brussels.

Esping-Andersen, G., Gallie, D., Hemerijck, A. and Myles, J. (2002), Why We Need a New Welfare State, Oxford: Oxford University Press.

European Commission (1999), 'Reconciliation of work and family life for men and women and the quality of care services', Report on Existing Research in the European Union, Office for Official Publications of the European Communities, Luxembourg.

European Commission (2000), 'Social policy agenda', Communication from the Commission to the Council, the European Parliament, the Economic and Social Committee and the Committee of the Regions, Office for Official Publications of the European Communities, Luxembourg.

EUROSTAT (2000), The Social Situation in the European Union 200o, Luxembourg: European Commission.

EUROSTAT (2001a), Statistical Yearbook on Candidate and South-East European Countries 2001, Luxembourg: European Commission.

EUROSTAT (2001b), Yearbook 2001: The Statistical Guide to Europe, Data 1989-1999, Brussels: Office for Official Publications of the European Communities.

Fagan, C., Warren, T. and McAllister, I. (2001), 'More or Less Work? Gender, Employment and Working-time Preferences in Europe', Report for the European Foundation on Living and Working Conditions, European Foundation for the Improvement of Living and Working Conditions, Dublin.

Fagan, C. (2001), 'Time, money and the gender order: work orientations and working time preference in Britain', Gender, Work and Organisation, 8: 3, 239-64.

Fagnani, J. (2002a), Family Policy, Life-Cycle and Linking Working Life and Family Life in France: Factors, New Choices to be Made, Lyon: ILO.

Fagnani, J. (2002b), 'The French 35 hour working law and the work-life balance of parents: friends or foes?', paper presented at the seminar 'Work, life and time in the new economy', London School of Economics, October.

Fajth, G. (1996), Family Support Policies in Central and Eastern Europe, Washington: National Academy of Sciences/National Research Council Task Force on Economies in Transition Workshop.

Ferge, Z. (1998), 'Women and social transformation in Central-Eastern Europe: the "old left" and the "new right", Social Policy Review, 10, Newcastle: Social Policy Association, pp. $217-36$.

Ferge, Z. and Tausz, K. (2002), 'Social security in Hungary: a balance sheet after twelve years', Social Policy and Administration, 36: 2, 176-99.

Fodor, E., Glass, C., Kawachi, J. and Popescu, L. (2002), 'Family policies and gender in Hungary, Poland, and Romania', Communist and Post-Communist Studies, 35: 4, 475-90.

Fraser, N. (1997), Justice Interruptus: Critical Reflections on the 'Postsocialist' Condition, New York and London: Routledge. 
Gershuny, J. (2000), Changing Times: Work and Leisure in Post-Industrial Society, Oxford: Oxford University Press.

Ginn, J., Street, D. and Arber, S. (2001), Women, Work and Pensions: International Issues and Prospects, Buckingham: Open University Press.

Glass, C. and Kawachi, J. (2001), Gender and Unemployment in Market Transition: Poland and Hungary Since 1988, Yale: Yale University.

Goodin, R.E. (2001), 'Work and welfare: towards a post-productivist welfare regime', British Journal of Political Science, 31: 13-39.

Gornick, J.C. and Meyers, M.K. (2003), Families that Work: Policies for Reconciling Parenthood and Employment, New York: Russell Sage Foundation Publications.

Grimshaw, D. and Rubery, J. (2001), The Gender Pay Gap: A Research Review, Manchester: Equal Opportunities Commission.

Haas, L. and Hwang, P. (1999), 'Parental leave in Sweden', in P. Moss and F. Deven (eds.), Parental Leave: Progress or Pitfall?, Brussels: NIDI CBGS Publications, pp. 45-68.

Hakim, C. (2000), Work-Lifestyle Choices in the Twenty-first Century: Preference Theory, Oxford: Oxford University Press.

Hancock, L. (2002), 'The care crunch: changing work, families and welfare in Australia', Critical Social Policy, 22: 1, 119-40.

Hantrais, L. (2002a), 'Central and East European states respond to socio-demographic challenges', Social Policy and Society, 1: 2, 141-50.

Hantrais, L. (2002b), Gendered Policies in Europe: Reconciling Employment and Family Life, London: Macmillan.

Hobson, B. (2002), Making Men into Fathers, Cambridge: Cambridge University Press.

Hochschild, A. (1989), The Second Shift, New York: Avon Books.

Jordan, B. (1989), The Common Good: Citizenship, Morality and Self-Interest, Oxford: Blackwell.

Jordan, B. (2000), Stumbling Towards Basic Income, London: Citizens Income Study Centre.

Knijn, T. (2001), 'Care work: innovations in the Netherlands', in M. Daly (ed.), Care Work: The Quest for Security, Geneva: ILO, pp. 159-74.

Knijn, T. and P. Selten (2002), 'Transformations of fatherhood', in B. Hobson (ed.), Making Men into Fathers: Men, Masculinities and the Social Politics of Fatherhood, Cambridge: Cambridge University Press, pp. 168-90.

Krause, E.L. (2003), 'Italy', in L. Walters (ed.), Women's Issues Worldwide: Europe, Connecticut and London: Greenwood Press.

Land, H. (2002a), Meeting the Child Poverty Challenge: why Universal Childcare is Key to Ending Child Poverty, London: Daycare Trust.

Land, H. (2002b), 'Spheres of care in the UK: separate and unequal', Critical Social Policy, 22: $1,13-32$.

Leira, A. (1999), 'Cash for child-care and daddy leave', in P. Moss and F. Deven (eds), Parental Leave: Progress or Pitfall?, Brussels: NIDI CBGS Publications, pp. 267-92.

Lewis, J. (2001a), The decline of the male breadwinner model: the implications for work and care', Social Politics, 8: 2, 152-70.

Lewis, J. (2001b), The End of Marriage: Individualism and Intimate Relations?, Cheltenham: Edward Elgar.

Lewis, J. (2002a), 'Gender and welfare state change', European Societies, 4: 4, 331-57.

Lewis, J. (2002b), 'The problem of fathers: policy and behaviour in Britain', in B. Hobson (ed.), Making Men into Fathers: Men, Masculinities and the Social Politics of Fatherhood, Cambridge: Cambridge University Press, pp. 125-49.

Lister, R. (1997), Citizenship: Feminist Perspectives, Basingstoke: Macmillan.

Mazey, S. (1998), 'The European Union and women's rights: from the Europeanization of national agendas to a European agenda?', Journal of European Public Policy, 5: 1, 131-52.

Micklewright, J. and Stewart, K. (2000), Child Well-Being in the EU and Enlargement to the East, Florence: International Child Development Centre.

Molyneux, M. (1990), 'The "woman question" in the age of Perestroika', New Left Review, 183: 23-59.

Morris, L. (1990), The Workings of the Household, Cambridge: Polity Press. 
Moss, P. and Deven, F. (1999), Parental Leave: Progress or Pitfall? Research and Policy Issues in Europe, Brussels: NIDI/CBGS Publications.

Moss, P. (2001), The UK at the Crossroads: Towards an Early Years European Partnership, London: Daycare Trust.

Mutari, E. and Figart, D. (2001), 'Europe at a crossroads: harmonization, liberalization, and the gender of work time', Social Politics, 8: 1, 36-64.

Neilson, J. (1998), 'Equal opportunities for women in the European Union: success or failure?', Journal of European Social Policy, 8: 1, 64-79.

Ostner, I. and Lewis, J. (1995), 'Gender and the evolution of European social policies', in S. Liebfried and P. Pierson (eds.), European Social Policy, Washington: The Brookings Institution, pp. $432-66$.

Ostner, I. (2000), 'From equal pay to equal employability: four decades of European gender policies', in M. Rossilli (ed.), Gender Policies in the European Union, New York: Peter Lang, pp. $25-42$.

Paoli, P. and Parent-Thirion, A. (2003), Working Conditions in the Acceding and Candidate Countries, Dublin: European Foundation for the Improvement of Living and Working Conditions.

Pascall, G. and Manning, N. (2000), 'Gender and social policy: comparing welfare states in Central and Eastern Europe and the former Soviet Union', Journal of European Social Policy, 10: 3, 269-96.

Pascall, G. and Manning, N. (2002), 'Social Europe East and West', in H. Ingham and M. Ingham (eds.), EU Expansion to the East: Prospects and Problems, Aldershot: Edward Elgar, pp. 134-161.

Phillips, A. (1991), Engendering Democracy, Cambridge: Polity Press.

Phillips, A. (1998), 'Democracy and representation: or why should it matter who our representatives are?', in A. Phillips (ed.), Feminism and Politics, Oxford: Oxford University Press, pp. 224-41.

Plantenga, J., Schippers, J. and Siergers, J. (1999), 'Towards an equal division of paid and unpaid work: the case of the Netherlands', Journal of European Social Policy, 9: 2, 99-110.

Plantenga, J. (2002), 'Combining work and care in the polder model: an assessment of the Dutch part-time strategy', Critical Social Policy, 22: 1, 53-71.

Rake, K. (2000), Women's Incomes over the Lifetime, London: The Stationery Office.

Rossilli, M. (1999), 'The European Union's policy on the equality of women', Feminist Studies, 25: $1,171-82$.

Rossilli, M. (2000), Gender Policies in the European Union, New York: Peter Lang.

Rubery, J., Smith, M., Fagan, C. and Grimshaw, D. (1998a), Women and European Employment, London: Routledge.

Rubery, J., Smith, M. and Fagan, C. (1998b), 'National working-time regimes and equal opportunities', Feminist Economics, 4: 1, 71-101.

Rubery, J., Smith, M. and Fagan, C. (1999), Women's Employment in Europe: Trends and Prospects, London: Routledge.

Siim, B. (2000), Gender and Citizenship, Cambridge: Cambridge University Press.

Squires, J. and Wickham-Jones, M. (2001), Women in Parliament: A Comparative Analysis, Manchester: Equal Opportunities Commission.

UNICEF (1998), 'Education for All? The Monee Project', Regional Monitoring Report No. 5, UNICEF International Child Development Centre, Florence.

UNICEF (1999), 'Women in transition', Regional Monitoring Report No. 6, UNICEF International Child Development Centre, Florence.

UNICEF (2001), 'A decade of transition', Regional Monitoring Report No. 8, UNICEF International Child Development Centre, Florence.

Walby, S. (1999), 'The new regulatory state: the social powers of the European Union', British Journal of Sociology, 50: 1, 118-37.

Walters, L. (2003), Women's Issues Worldwide: Europe, Connecticut and London: Greenwood Press.

Williams, F. (2001), 'In and beyond New Labour: towards a new political ethics of care', Critical Social Policy, 21: 69, 467-93. 